\title{
Descriptive Survey of Depression in India
}

\author{
${ }^{1}$ Department of Psychiatric Nursing, DIMHANS, India \\ ${ }^{2}$ Dhanush institute of Nursing Sciences, India \\ ${ }^{3}$ Indira Gandhi Children's Hospital, India \\ ${ }^{4}$ Department of Management Studies. Karnataka Arts College, India \\ ${ }^{5}$ Department of Civil Engineering, MSRUAS, India \\ ${ }^{6} R L$ Law College, India
}

Susheel Kumar V Ronadi*, Chetan S Patali², Shridhar H Gondbal ${ }^{3}$, Kiran Kumar TC 4 , Mallikarjuna Ronad ${ }^{5}$, Pankaja TC ${ }^{6}$, Rajendra Badesgol ${ }^{7}$ and Peekesh Kumar J Singhal ${ }^{8}$

${ }^{7}$ Department of Police, India

${ }^{8} \mathrm{HOD}$ of Psychiatric Nursing, Institute of Medical Technology and Nursing Education, India

Submission: May 28, 2018; Published: August 24, 2018

*Corresponding author: Susheel Kumar V Ronad, Department of Psychiatric Nursing, Dharwad Institute of Mental Health and Neurosciences, India, Email: susheelronad@gmail.com

News

WHO's new global health estimates on depression said while over 5 crore Indians suffered from depression, over 3 crore others suffered from anxiety disorders. The WHO report says over twothirds of global suicides in 2015 were in low- and middle-income countries like India. The WHO report says over two-thirds of global suicides in 2015 were in low- and middle-income countries like India.

New Delhi: Over five crore Indians suffered from depression, a major contributor to global suicides which occurred mainly in low- and middle-income countries like India in 2015, a WHO study has said. The World Health Organization in its new global health estimates on depression for 2015 said while over five crore Indians suffered from depression, over three crore others suffered from anxiety disorders. The report titled 'Depression and Other Common Mental Disorders - Global Health Estimates' said over two-thirds of global suicides were in low- and middleincome countries like India in 2015.

The WHO document said that 322 million people are living with depression worldwide and nearly half of them live in South East Asian and Western Pacific region, reflecting relatively large populations of India and China. "The total number of people living with depression in the world is 322 million. Nearly half of these people live in the South-East Asia Region and Western Pacific Region, reflecting the relatively larger populations of those two Regions which include India and China," the document said. The total estimated number of people living with depression increased by 18.4\% between 2005 and 2015, it said. According

to WHO figures, the total cases of depressive disorders in 2015 in India were 5,66,75,969 which was 4.5\% of population in 2015 while total cases of anxiety disorders were $3,84,250,93$ which was $3 \%$ of the population in the same year period.

For depressive disorders, WHO said total Years Lived with Disability (YLD) in India was 1,00,504,11 which was 7.1\% of total YLD, for anxiety disorders, total years for YLD was 35,19,527 which was $2.5 \%$ of total YLD.

The document noted that in 2015 , an estimated $7,88,000$ people died due to suicide while many more than this number attempted but did not die. It said suicide accounted for close to $1.5 \%$ of all deaths worldwide, bringing it into the top 20 leading causes of death in 2015.

"Suicide occurs throughout the lifespan and was the second leading cause of death among 15-29year old globally in 2015," it said. The suicide rate varies by WHO Region and by sex, ranging from below 5 per 100,000 population among females in lowand middle-income countries of the Eastern Mediterranean and American Regions to 20 or more among males in high-income countries and also in the low- and middle-income countries of the African, European and South-East Asian Regions. 78\% of global suicides occurred in low- and middle-income countries in 2015," it said. India accounted for the highest estimated number of suicides in the world in 2012, according to a WHO report published in 2014 which found that one person commits suicide every 40 seconds globally. 
Depression is the leading cause of disability worldwide and is a major contributor to the overall global burden of disease, WHO said and asserted that more women are affected by depression than men and at its worst, depression can lead to suicide.

\section{Your next submission with Juniper Publishers will reach you the below assets}

- Quality Editorial service

- Swift Peer Review

- Reprints availability

- E-prints Service

- Manuscript Podcast for convenient understanding

- Global attainment for your research

- Manuscript accessibility in different formats

( Pdf, E-pub, Full Text, Audio)

- Unceasing customer service

Track the below URL for one-step submission https://juniperpublishers.com/online-submission.php 